\title{
Епідеміологія ішемічної хвороби серця та інфаркту міокарда в Закарпатській області
}

\author{
ДВНЗ «Ужгородський національний університет», м. Ужгород, Україна
}

\begin{abstract}
В статті наведено дані про поширеність імемічної хвороби серия та інфаркту міокарда серед дорослого населення Закарпатської області та захворюваність дорослого населення на вказані хвороби в динаміці 2014-2018 років. Захворюваність дорослого населення області на всі форми ішемічної хвороби серия має тенденцію до зростання, а на ішемічну хворобу серия, яка проявляється стенокардією навпаки має тенденцію до скорочення. Поширеність всіх форм ішемічної хвороби серия має тенденщію до скорочення, а тих форм, які проявляються стенокардією - до зростання. Захворюваність дорослого населення Закарпатської області на гострий інфаркт міокарда теж має тенденцію до зростання.

Ключові слова: ішемічна хвороба серия, інфаркт міокарда, захворюваність, поширеність.
\end{abstract}

\section{Ветуп}

$I_{\mathrm{r}}$ шемічна хвороба серця (IXC) $€$ однією 3 головних причин високої смертності, втрати працездатності та зниження якості життя дорослого населення як у світі та і в Україні [9].

В Україні поширеність та захворюваність на IXC щорічно зростає і складає серед дорослого населення $34,9 \%$ і 26,8\%, серед осіб працездатного віку 26,7 і 23,1\% відповідно. Смертність від IXC складає близько 650 на 100 тис. населення [2, 8].

За визначенням Всесвітньої Організації Охорони Здоров'я (ВОО3), неінфекційні захворювання (НI3) в XXI столітті стали одною із головних проблем для систем охорони здоров'я, негативно впливають на сталий розвиток і соціально-економічну структуру країн світу [10, 11]. Боротьба 3 епідемією НІЗ і факторами ризику їх розвитку дозволяє врятувати мільйони людських життів і зменшити стрімко зростаючі витрати на медичну допомогу. В разі без діяльності, за прогнозами ВООЗ до 2030 р., НІЗ щорічно будуть причиною 52 млн смертей [1].

Мета роботи - дослідити епідеміологію ішемічної хвороби серця та інфаркту міокарда в Закарпатській області.

\section{Матеріали та методи}

Матеріалами дослідження служити дані галузевої статистичної звітності в Закарпатській області [3-7]. Під час дослідження використано медико-статистичний метод та метод структурно-логічного аналізу. Дослідженням охоплено період з 2014 по 2018 роки.

\section{Результати дослідження та їх обговорення}

На початку дослідження було вивчено та проведено аналіз щодо захворюваності дорослого населення
Закарпатській області на ішемічну хворобу серця та дані про іiі поширеність. Отримані дані наведено в табл. 1.

Аналіз наведених в табл. 1 даних вказує на те, що захворюваність на всі форми ішемічної хвороби серця дорослого населення області як в абсолютних даних так і в показнику на 100 тис. дорослого населення має тенденцію до зростання 3 найбільшим показником в 2016 році: 18672 та 1934,7 відповідно. Захворюваність дорослого населення області на ішемічну хворобу серця, яка проявляється стенокардією навпаки має тенденцію до скорочення. Вона в 2018 році склала відповідно 5065 та 526,0.

Поширеність всіх форм ішемічної хвороби серця скоротилася в абсолютних числах на 4,3\% і склала 242602 зареєстрованих хворих. В розрахунку на 100 тис. дорослого населення показник поширеності ішемічної хвороби скоротився на 4,0\% і склав 25191,8. При цьому під диспансерним наглядом в закладах охорони здоров'я області знаходилося 86,4\% осіб, які страждають на всі форми ішемічної хвороби серця. Поширеність серед дорослого населення ішемічної хвороби серця яка проявляється стенокардією навпаки має тенденцію до зростання з рівнем 8988,1 на 100 тис дорослого населення в 2018 році. При цьому під диспансерним наглядом в закладах охорони здоров»я області знаходилося 83,7\% осіб, які страждають на дану форму IXC.

Відповідно до програми дослідження далі було вивчено та проаналізовано дані щодо захворюваності дорослого населення Закарпатської області на гострий інфаркт міокарда за період 2014-2018 роки. Отримані результати наведено в табл. 2.

Аналіз наведених в табл. 2 даних вказує на високі рівні захворюваності дорослого населення Закарпатської області на гострий інфаркт міокарда які мають тенденцію до зростання. Так, в 2018 році в області було зареєстровано 1052 випадків захворюваності дорослого населення Закарпатської області на гострий інфаркт міокарда, що 
склало 109,2 випадки на 100 тис. дорослого населення. Найвищі рівні захворюваності дорослого населення Закарпатської області на гострий інфаркт міокарда було зареєстровано в 2015 році: 1099 та 113,7 відповідно.
Далі були вивчені та проаналізовані показники захворюваності дорослого населення Закарпатської області на гострий трансмуральний інфаркт міокарда в динаміці 2014-2018 років. Отримані дані наведено в табл. 3.

Таблиия 1

Захворюваність дорослого населення Закарпатської області на ішемічну хворобу серця та її поширеність, 2014-2018 роки

\begin{tabular}{|c|c|c|c|c|c|}
\hline & 2014 & 2015 & 2016 & 2017 & 2018 \\
\hline \multicolumn{6}{|c|}{ Захворюваність на ішемічну хворобу серця (всі форми) } \\
\hline Абсолютна кількість & 16888 & 17956 & 18672 & 17565 & 17038 \\
\hline На 100 тис. дорослого населення & 1748,0 & 1857,3 & 1934,7 & 1822,2 & 1769,2 \\
\hline \multicolumn{6}{|c|}{ Захворюваність на ішемічну хворобу серця (хворі на стенокардію) } \\
\hline Абсолютна кількість & 6710 & 5867 & 6014 & 5650 & 5065 \\
\hline На 100 тис. дорослого населення & 694,5 & 606,8 & 623,1 & 586,1 & 526,0 \\
\hline \multicolumn{6}{|c|}{ Поширеність ішемічної хвороби серця (всі форми) } \\
\hline Абсолютна кількість & 253309 & 248348 & 249948 & 246358 & 242602 \\
\hline На 100 тис. дорослого населення & 26219,0 & 25687,6 & 25898,0 & 25557,6 & 25191,8 \\
\hline Повнота охоплення диспансерним наглядом (\%) & 87,9 & 87,3 & 88,8 & 87,8 & 86,4 \\
\hline \multicolumn{6}{|c|}{ Поширеність ішемічної хвороби серця (хворі на стенокардію) } \\
\hline Абсолютна кількість & 85096 & 85152 & 90198 & 88458 & 86557 \\
\hline На 100 тис. дорослого населення & 8807,9 & 8807,6 & 9345,7 & 9176,3 & 8088,1 \\
\hline Повнота охоплення диспансерним наглядом (\%) & 87,8 & 87,3 & 88,1 & 84,7 & 83,7 \\
\hline
\end{tabular}

Табличя 2

Захворюваність дорослого населення Закарпатської області на гострий інфаркт міокарда, 2014-2018 роки

\begin{tabular}{|l|c|c|c|c|c|c|}
\hline & $\mathbf{2 0 1 4}$ & $\mathbf{2 0 1 5}$ & $\mathbf{2 0 1 6}$ & $\mathbf{2 0 1 7}$ & $\mathbf{2 0 1 8}$ \\
\hline Абсолютна кількість & 1041,0 & 1099,0 & 1072 & 1075,0 & 1052,0 \\
\hline На 10 тис. дорослого населення & 107,7 & 113,7 & 111,1 & 111,5 & 109,2 \\
\hline
\end{tabular}

Табличя 3

Захворюваність дорослого населення Закарпатської області на гострий трансмуральний інфаркт міокарда, 2014-2018 роки

\begin{tabular}{|l|c|c|c|c|c|c|}
\hline & $\mathbf{2 0 1 4}$ & $\mathbf{2 0 1 5}$ & $\mathbf{2 0 1 6}$ & $\mathbf{2 0 1 7}$ & $\mathbf{2 0 1 8}$ \\
\hline Абсолютна кількість & 690,0 & 707,0 & 701 & 764,0 & 750,0 \\
\hline На 10 тис. дорослого населення & 71,4 & 73,1 & 72,6 & 79,3 \\
\hline
\end{tabular}

Проведений аналіз даних табл. 3 вказує на те, що рівень захворюваності дорослого населення Закарпатської області на гострий трансмуральний інфаркт міокарда за період 2014-2018 роки зріс на 8,7\% і склав 750 осіб або 77,9 на 10 тис. населення.
Відповідно до програми дослідження наступним кроком було вивчення рівня диспансеризації населення Закарпатської області, що перенесло гострий інфаркт міокарда в динаміці 2014-2018 років. Отримані результати наведено в табл. 4.

Таблиця 4

Диспансеризація населення Закарпатської області, що перенесло гострий інфаркт міокарда, 2014-2018 роки

\begin{tabular}{|l|c|c|c|c|c|c|}
\hline & $\mathbf{2 0 1 4}$ & $\mathbf{2 0 1 5}$ & $\mathbf{2 0 1 6}$ & $\mathbf{2 0 1 7}$ & $\mathbf{2 0 1 8}$ \\
\hline Перебуває під диспансерним наглядом, абс. & 158,0 & 194,0 & 208 & 172,0 & 175,0 \\
\hline На 10 тис. дорослого населення & 16,4 & 20,1 & 21,6 & 17,8 & 18,2 \\
\hline Повнота охоплення диспансерним наглядом (\%) & & 17,7 & 19,4 & 16,0 & 16,6 \\
\hline
\end{tabular}


Негативним показником профілактичної діяльності системи охорони здоров'я області є рівень охоплення диспансеризацією осіб, що перенесли гострий інфаркт міокарда. В області він складає 16,6\%. Це означає, що $83,4 \%$ осіб, що перенесли гострий інфаркт міокарда не пройшли необхідну реабілітацію і не отримують необхідну підтримуючу терапію.

Далі було вивчення в динаміці 2014-2018 років рівня диспансеризації населення Закарпатської області, що перенесло гострий трансмуральний інфаркт міокарда. Отримані дані наведено в табл. 5.

Із загальної кількості осіб, що перенесли гострий трансмуральний інфаркт міокарда під диспансерним наглядом перебуває 16,0\%. Це означає, що 84,0\% осіб, що перенесли гострий трансмуральний інфаркт міокарда підвержені ризику розвитку повторного інфаркту міокарда, хронічної серцево-судинної недостатності, зниження якості життя.

Табличя 5

Диспансеризація населення Закарпатської області, що перенесло гострий трансмуральний інфаркт міокарда, 2014-2018 роки

\begin{tabular}{|l|c|c|c|c|c|}
\hline & $\mathbf{2 0 1 4}$ & $\mathbf{2 0 1 5}$ & $\mathbf{2 0 1 6}$ & $\mathbf{2 0 1 7}$ & $\mathbf{2 0 1 8}$ \\
\hline Перебуває під диспансерним наглядом, абс. & 93,0 & 118,0 & 120 & 116,0 & 120,0 \\
\hline На 10 тис. дорослого населення & 9,6 & 12,2 & 12,4 & 12,0 & 12,5 \\
\hline Повнота охоплення диспансерним наглядом (\%) & & 16,7 & 17,1 & 15,2 & 16,0 \\
\hline
\end{tabular}

\section{Висновки}

В ході дослідження встановлено, що захворюваність дорослого населення області на всі форми ішемічної хвороби серця має тенденцію до зростання, а на ішемічну хворобу серця, яка проявляється стенокардією навпаки має тенденцію до скорочення. Поширеність всіх форм ішемічної хвороби серця має тенденцію до скорочення, а тих форм, які проявляються стенокардією до зростання. Захворюваність дорослого населення Закарпатської області на гострий інфаркт міокарда теж має тенденцію до зростання.

Перспективи подальших досліджень пов'язані 3 вивченням якості життя осіб, що перенесли інфаркт міокарда.

\section{Література}

1. Доклад о ситуации в области неинфекционных заболеваний в мире 2014 г. (резюме). ВОЗ. - 16 с.

2. Коваленко В.М. Серцево-судинні хвороби: медично-соціальне значення та стратегія розвитку кардіології в Україні / В.М. Коваленко, А.П. Дорогой // Український кардіологічний журнал. - 2016, додаток 3. - С. 5-15.

3. Мережа закладів та основні показники діяльності системи охорони здоров'я Закарпатської області за 2014 рік. Закарпатський обласний медичний інформаційно-аналітичний центр. Ужгород, 2015. - 110 с.

4. Мережа закладів та основні показники діяльності системи охорони здоров'я Закарпатської області за 2015 рік. Закарпатський обласний медичний інформаційно-аналітичний центр. Ужгород, 2016. - 123 с.

5. Мережа закладів та основні показники діяльності системи охорони здоров'я Закарпатської області за 2016 рік. Закарпатський обласний медичний інформаційно-аналітичний центр. Ужгород, 2017. - 129 с.

6. Мережа закладів та основні показники діяльності системи охорони здоров'я Закарпатської області за 2017 рік. Закарпатський обласний медичний інформаційно-аналітичний центр. Ужгород, 2018. - 144 с.

7. Мережа закладів та основні показники діяльності системи охорони здоров'я Закарпатської області за 2018 рік. Закарпатський обласний медичний інформаційно-аналітичний центр. Ужгород, 2019. - 152 с.

8. Мировая статистика здравоохранения 2014 г.: значительный рост продолжительности жизни. - ВОЗ.

9. Хвороби системи кровообігу як медико-соціальна і суспільно-політична проблема (аналітично-статистичний посібник) / Під ред. Коваленка В.М., Корнацького В.М. - Київ, 2014. - 280 с.

10. http://www.who.int/mediacentre/news/releases/2014/world-health-statistics-2014/ru.

11. http://www.who.int/nmh/publications/ncd-status-report-2014/ru. 
Эпидемиология ишемической болезни сердца и инфаркта миокарда в Закарпатской области

Кошеля И.И., Скрип В.В. Ужгородский национальный университет

В статье приведены данные о распространенности ишемической болезни сердца и инфаркта миокарда среди взрослого населения Закарпатской области и заболеваемость взрослого населения указанными заболеваниями в динамике 2014-2018 годов. Заболеваемость взрослого населения области всеми формами ишемической болезни сердца имеет тенденцию к росту, а ишемической болезнью сердца, которая проявляется стенокардией, наоборот имеет тенденцию к снижению. Распространенность всех форм ишемической болезни сердца имеет тенденцию к сокращению, а тех форм, которые проявляются стенокардией - к росту. Заболеваемость взрослого населения Закарпатской области острым инфарктом миокарда также имеет тенденцию к росту.

Ключевые слова: ишемическая болезнь сердца, инфаркт миокарда, заболеваемость, распространенность.

\section{Epidemiology of ischaemic heart disease and myocardial infarction in Transcarpathian region}

Koshelya I.I., Skryp V.V. Uzhhorod National University

The article provides data on the prevalence of ischaemic heart disease and myocardial infarction among the adult population of Transcarpathian region and the morbidity of adult population for these diseases in the dynamics of the years 2014-2018. The morbidity of adult population for all forms of ischaemic heart disease tends to increase, and for ischaemic heart disease which manifests itself as sthenocardia on the opposite tends to reduce. The prevalence of all forms of ischemic heart disease tends to reduce, and those forms, which are manifested by sthenocardia - to growth. The morbidity of adult population in Transcarpathian region for acute myocardial infarction also tends to increase.

Key words: coronary heart disease, myocardial infarction, morbidity, prevalence.

\section{Відомості про авторів}

Кошеля Іван Іванович - к.мед.н., пошукувач ДУ «УІСД МОЗ України»; 02099 м. Київ, пров. Волго-Донський, 3.

Скрип Василь Васильович - к.мед.н., доцент ДВНЗ «Ужгородський національний університет»; 88001, м. Ужгород, пл. Народна, 3. 